Revista Mídia e Cotidiano

ISSN: 2178-602X

Artigo Seção Livre

Volume 14, Número 1, jan-abr de 2020

Submetido em: 07/11/2019

Aprovado em: 13/02/2020

\title{
Os memes como retórica depreciativa nas relações entre Barra do Garças (MT) e Aragarças (GO)
}

\section{Memes as derogatory rhetoric in the relationship between the cities of Barra do Garças (MT) and Aragarças (GO)}

\author{
Bruna Alves da SILVA ${ }^{1}$ \\ Eliézer Cardoso de OLIVEIRA ${ }^{2}$ \\ Maria de Fátima OLIVEIRA ${ }^{3}$
}

\begin{abstract}
Resumo
Este estudo analisa os diversos memes produzidos e difundidos por moradores de Barra do Garças (MT) que retratam negativamente Aragarças (GO). As duas cidades são contíguas em termos espaciais e possuem indicadores socioeconômicos parecidos, sendo separadas por uma ponte sobre o Rio Araguaia. Esses discursos pejorativos em forma de memes foram analisados a partir do referencial elaborado por Norbert Elias e John Scotson (2000) em Os estabelecidos e os outsiders, e com base na análise de Freud (2010) sobre o narcisismo das pequenas diferenças. A hipótese do artigo é que os discursos depreciativos presentes nos memes servem para demarcar a distinção identitária entre as duas cidades, servindo para reforçar uma distinção simbólica, que separa o "nós" do "outro".
\end{abstract}

Palavras-chave: Barra do Garças. Aragarças. Memes. Retórica depreciativa.

\begin{abstract}
This study analyzes the various memes produced and disseminated by residents of Barra do Garças (Mato Grosso), which presented negative portrayals about the city of Aragarças (Goiás). The two cities are spatially contiguous and have similar socioeconomic indicators, being separated by a bridge over the Araguaia River. These pejorative discourses presented as memes were analyzed based on the framework developed by Norbert Elias and John Scotson (2000) in The Established and The Outsiders. We also

\footnotetext{
${ }^{1}$ Mestre em Ciências Sociais e Humanidades (UEG). Servidora da Secretaria Municipal de Educação de Goiânia (SME) e Professora da Educação Básica (Rede Privada). E-mail: brunalvesilva1@gmail.com. ORCID: 0000-0003-4647-604X.

${ }^{2}$ Doutor em Sociologia (UnB). Professor do curso de graduação em História e do Mestrado Territórios e Expressão Cultural no Cerrado da Universidade Estadual de Goiás (UEG)/Anápolis. E-mail: ezi@uol.com.br. ORCID: 0000-0001-7763-7454. Programa de Mestrado Interdisciplinar Territórios e Expressões Culturais no Cerrado (TECCER) da Universidade Estadual de Goiás (UEG). E-mail: proffatima@ hotmail.com. Orcid: 0000-0002-9519-8093.
}

${ }^{3}$ Doutora em História pela Universidade Federal de Goiás (UFG). Docente do Curso de História e do
\end{abstract}




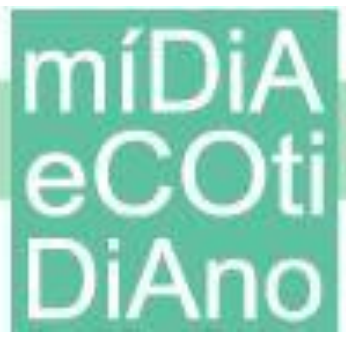

draw from Freud's analysis (2010) on narcissism of small differences. The hypothesis of the article is that the derogatory discourses found in memes serve to demarcate identity distinctions between the two cities, reinforcing a symbolic distinction, which separates "us" from the "others".

Keywords: Barra do Garças. Aragarças. Memes. Derogatory rhetoric.

\section{Introdução}

O avanço acelerado da tecnologia eletrônica e informática das últimas décadas e sua popularização têm transformando o cotidiano das pessoas interferindo no modo que se comunicam, acessam informações e as compartilham entre si. A produção e disseminação de imagens e textos, tanto por profissionais quanto por qualquer indivíduo comum têm se proliferado para além das relações sociais locais. Essa prática, além de ampliar a divulgação de informações, tem conectado pessoas desconhecidas de diversas partes do planeta. Nesse contexto, os memes têm conquistado lugar de destaque nas mídias sociais como um meio jocoso de entretenimento e comunicação visual. Por meio dessa linguagem é possível provocar emoções, opiniões e reações tanto por parte de quem produz como de quem compartilha e visualiza os memes.

Para uma melhor compreensão e análise dos memes nos próximos tópicos, os estudos do biólogo evolucionista Richard Dawkins (2014) foram importantes. Para ele, quase tudo que é incomum no homem pode ser resumido na palavra cultura, pois a transmissão cultural é análoga à transmissão genética. Desse modo, buscando um substantivo para significar uma unidade de transmissão cultural, ou uma unidade de imitação, Dawkins propôs o termo meme, em analogia ao termo gene. Nesse sentido, uma das principais categorias teóricas do artigo foi uma reflexão sobre os memes, termo difundido a partir das ideias de Richard Dawkins, que indica a proliferação de discursos de forma maciça na Internet. No caso desse estudo, os memes possuem uma retórica depreciativa, tendo como alvo os moradores da cidade de Aragarças (GO).

Assim, em termos metodológicos, a pesquisa se desenvolveu em diálogos com autores que trabalharam temáticas estruturante desta reflexão. Isto é, além do já citado Dawkins, como o conflito entre duas cidades contíguas em termos espaciais é outra chave da nossa abordagem, valemo-nos das reflexões desenvolvidas por Norbert Elias e John 
Scotson (2000), no estudo que desenvolveram sobre um conflito entre os moradores antigos (os estabelecidos) e os mais recentes (outsiders) numa cidade inglesa que resultaram em práticas de inferiorização do outro. Para uma melhor compreensão da motivação desses discursos, o texto também recorre à ideia de "narcisismo das pequenas diferenças", um conceito desenvolvido por Freud que explica as distinções identitárias entre grupos situados próximos uns aos outros. Já em relação ao corpus da pesquisa, este foi construído a partir dos memes encontrados, em sua maioria, na página do Facebook "BG mil graus". Essa página foi criada em 2016 e é classificada como sendo de entretenimento, divulgando eventos culturais da cidade de Barra do Garças. Seu conteúdo é regionalizado, sendo que em novembro de 2019 era seguida por 42.902 pessoas e havia recebido mais de 40 mil curtidas. A página não segue uma regra em suas publicações, intercalando centenas de memes que exaltam as belezas e/ou construções arquitetônicas de Barra do Garças, outros que ironizam os problemas de infraestrutura de alguns bairros da cidade e aqueles que caçoam da cidade e dos moradores de Aragarças. Desses, as temáticas variam entre problemas de infraestrutura urbana, financeira, moda/vestuário e a suposta predisposição dos aragarcenses ao crime e à violência.

Nos memes veiculados pela página "BG mil graus" os adjetivos/classificações, recorrem, não poucas vezes, à ironia, escárnio ou humor, sendo que, nem todos - vale ressaltar - são sobre os aragarcenses e a cidade. Assim, optamos por selecionar aqueles que indicavam algumas das características/classificações mais exploradas ou repetidas na temática que focamos, já que nosso objetivo é também demonstrar o poder corrosivo das pilhérias sobre a imagem dos aragarcenses e da cidade. O período dos posts selecionados para análise e discussão que faremos neste artigo foi entre setembro de 2017 e abril de 2018, sendo que dos dezessete memes catalogados na pesquisa, selecionamos os nove mais expressivos para este estudo. Ressaltamos ainda que, além da página difusora dos memes, o artigo também considerou para as discussões propostas, informações estatísticas de caráter socioeconômico de modo a contextualizar as diferenças e semelhanças entre as duas cidades.

Este percurso resultou numa divisão em três seções. Na primeira apresentamos uma rápida contextualização histórica das duas cidades visando uma melhor compreensão da relação entre elas e procurando mostrar o efeito das transformações no modo como os 


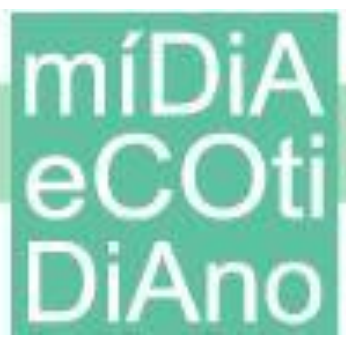

moradores fundamentam a sua identidade. Em seguida, são analisadas as estratégias de depreciação discursiva do outro como construção identitária a partir de uma discussão bibliográfica que envolve diversos autores, inclusive os já citados Norbert Elias e John Scotson (2000) e Sigmund Freud (2010). E, na última seção o estudo foca na apresentação e análise dos memes selecionados - que possuem caráter depreciativo - sobre a cidade e a população de Aragarças.

\section{Barra do Garças (MT) e Aragarças (GO)}

No encontro entre os rios Garças e Araguaia, na fronteira entre os estados de Goiás e Mato Grosso, estão localizadas as cidades de Barra do Garças (MT) e Aragarças (GO), ambas reconhecidas por serem polos de atração de turistas, principalmente pelas belas praias de areias brancas nas margens dos rios. Os núcleos urbanos iniciais das duas cidades surgiram a partir da segunda década do século $\mathrm{XX}$, quando imigrantes nordestinos chegaram à região em busca de diamantes e fundaram os povoados de Barra Goiana e Barra Cuiabana (SILVA, 2019, p. 12).

Em 1943, dentro do projeto varguista da Marcha para o Oeste, o povoado de Barra Goiana foi escolhido para sediar a Fundação Brasil Central (FBC), com o objetivo de estimular o povoamento e o desenvolvimento do interior brasileiro. Em 1951, o povoado torna-se vila com o nome de Aragarças e, em 1953, torna-se município emancipado (MACIEL, 2006; DINIZ, 2016). Graças aos investimentos da Fundação, Aragarças passou a contar com equipamentos urbanos típicos dos grandes centros, como hotel, hospital, aeroporto, casas de alvenarias e, também, com luz elétrica, fábricas e oficinas. Os moradores, principalmente aqueles que trabalhavam na FBC - denominados de "fichados" - passaram a se sentir orgulhosos do progresso da cidade, como demonstram os epítetos "a cidade encantada do sertão", "princesinha do Araguaia", “princesinha do oeste" e "cidade-mar do sertão" (RIBEIRO, 2016, p. 29). Mas os efeitos modernizadores da FBC não foram exclusivos de Barra Goiana: eles também contemplaram o distrito de Barra Cuiabana, do outro lado do rio Araguaia. Graças ao intenso crescimento demográfico, em 1948 este distrito transmuda o seu nome para Barra do Garças e torna-se sede administrativa do município, passando a contar com agências bancárias e escolas de diversos níveis educacionais (VARJÃO, 1985, p. 97). 
Após a chegada da FBC, os dois núcleos populacionais passam a usufruir das benesses modernizadoras de forma diferenciada: Aragarças era o lugar onde os moradores tinham acesso a atendimento médico, aos empregos institucionalizados e aos jornais e revistas por meio do Correio Aéreo; e em Barra do Garças estava se formando um polo comercial, com lojas, bancos e serviços (LIMA FILHO, 2001, p. 124). A interação entre os dois lugares era um pouco prejudicada devido à necessidade de balsas de madeiras e pequenos barcos para atravessar os caudalosos rios Garças e Araguaia (SILVA, 2019, p. 63). Assim, na década de 1950, as interações sociais tornaram-se facilitadas com a construção da Ponte João Alberto Lins de Barros, iniciada em 1953 e inaugurada em 1957, interligando as duas cidades e propiciando um intenso fluxo comercial entre Goiás e Mato Grosso. No âmbito cotidiano, as relações sociais entre os habitantes ficaram mais constantes, já que se podia ir de uma cidade a outra em questão dos poucos minutos necessários para atravessar os 150 metros de comprimento da ponte (IMPRENSA POPULAR, 7 jan. 1957). Como as duas cidades ficaram mais "próximas" uma da outra, foi possível perceber de forma mais contundente as pequenas diferenças existentes entre elas.

Em 1967, o Governo Federal extinguiu a Fundação Brasil Central, retirando de Aragarças importantes equipamentos institucionais, como o atendimento em hospital federal, as festas no Hotel Getúlio Vargas e a interligação com outras regiões por meio da Força Aérea Brasileira (SILVA, 2019, p. 87). Assim, os “tempos áureos" da época FBC sobreviveram apenas na memória nostálgica dos pioneiros, agora temerosos em relação ao futuro da cidade sem as verbas federais (LIMA FILHO, 2000, p. 81).

Por outro lado, Barra do Garças foi beneficiada pela expansão da fronteira agrícola no Mato Grosso, quando imigrantes sulistas adquiriram terras e desenvolveram uma produção voltada para o agronegócio. O polo comercial da cidade cresceu ainda mais com o agronegócio e com a posição estratégica da cidade, ligando a produção de Mato Grosso ao sudeste brasileiro. De acordo com Cunha (2006), esse percurso diferenciado resultou em desenvolvimento também diferenciado entre as duas cidades, tornando Barra do Garças mais pujante em termos demográficos, econômicos e sociais do que a sua rival. Essas diferenças propiciaram o aparecimento de discursos imagéticos, entre eles os memes, que passaram a ironizar e depreciar a cidade e a população de Aragarças. 


\section{A depreciação discursiva do outro como estratégia identitária}

Gregos e bárbaros, judeus e gentios, cristãos e infiéis, romanos e cartaginenses. São muitas as estratégias de construção identitária utilizando o outro como oposição. O historiador François Hartog (2014, p. 40), no livro O espelho de Heródoto, percebeu que as narrativas elaboradas pelos gregos sobre os bárbaros tinham "a preocupação de traduzir o outro em termos do saber compartilhado pelos gregos e que, para fazer crer no outro que constrói, elabora toda uma retórica de alteridade". O outro é um espelho para enxergar a si mesmo. Logicamente, essa estratégia, em vários outros lugares, legitimou a perseguição do outro, sendo o caso mais extremo o da República Romana, cujo bordão Delenda est Carthago, insistentemente proferida por Catão e outros políticos, culminou com o extermínio da cidade inimiga.

O caso analisado neste artigo não é tão extremo assim, pois o "outro" não fala uma língua totalmente incompreensível (como a dos bárbaros para os gregos), não adora falsos deuses (como os gentios para os judeus ou os muçulmanos para os cristãos) e não é um rival econômico (como Cartago para os romanos). No caso da oposição entre barragarcenses e aragarcenses, o outro fala a mesma língua, veste-se de modo parecido, a maioria da população professa uma fé de matriz cristã e tem praticamente o mesmo padrão econômico e cultural. A única diferença significativa para justificar uma retórica depreciativa é a de que o "outro" mora do outro lado da ponte, a poucos metros de distância.

No caso do vale do Araguaia, o que se percebe é uma situação muito parecida da analisada por Norbert Elias e John Scotson (2000), em uma cidade inglesa que os pesquisadores imputaram o nome fictício de Wiston Parva. O lugar era formado por três zonas setoriais: a primeira, habitada pelas famílias antigas de classe média; a segunda, composta por famílias antigas de operários; e a terceira, formada por trabalhadores londrinos que chegaram ao local mais recentemente por causa da II Guerra Mundial. Os habitantes da zona 3 passaram a ser estigmatizados pelos habitantes da 1 e da 2 , simplesmente porque o loteamento no qual eles moravam era mais recente e eles não faziam parte da tradição do lugar. Desse modo,

O grupo estabelecido cerrava fileiras contra eles e os estigmatizava, de maneira geral, como pessoas de menor valor humano. Considerava-se 
que lhes faltava a virtude humana superior - o carisma grupal distintivo - que o grupo dominante atribuía a si mesmo (ELIAS; SCOTSON, 2000, p. 19).

As diferenças econômicas, étnicas e religiosas entre as três zonas eram insignificantes. A única distinção que serviu para separar os "estabelecidos" (os mais antigos) dos "outsiders" (os de fora) foi a antiguidade. Por meio de uma rede de fofocas, os "outsiders" foram generalizados como delinquentes, pessoas com moral frouxa, barulhentas e descontroladas no uso de bebidas alcoólicas. $\mathrm{Na}$ verdade, entre os "estabelecidos" havia pessoas com os mesmos defeitos morais que eles atribuíam aos “outsiders", mas eles fizeram uma operação metonímica, atribuindo "ao conjunto do grupo outsider as características 'ruins' de sua porção 'pior' - de sua minoria anômica" (ELIAS; SCOTSON, 2000, p. 22).

Como os “estabelecidos” se conheciam há duas ou três gerações eles possuíam uma maior coesão social e foram vitoriosos na guerra discursiva contra os moradores mais recentes. Desse modo, os próprios "outsiders" internalizaram os insultos e passaram a se sentir inferiores em relação aos "estabelecidos". Isso ocorreu porque "o estigma social imposto pelo grupo mais poderoso ao menos poderoso costuma penetrar na autoimagem deste último e, com isso, enfraquecê-lo e desarmá-lo" (ELIAS; SCOTSON, 2000, p. 24). No caso de Winston Parva, a depreciação do outro ia além de uma retórica discursiva e configurava as relações da sociabilidade cotidiana, pois "os estabelecidos excluíam todos os membros do outro grupo de contato social não profissional com seus próprios membros" (idem n. a., p 20). Interagir com os "outsiders" além do mínimo necessário tornou-se um tabu condenado por meio de fofocas. Essa situação era evidentemente desconfortável para os “outsiders", principalmente entre os mais jovens que passaram a manifestar raiva das "pessoas por quem se sentiam rejeitados e que lhes recusavam nem bem sabiam o quê" (idem n. a., p. 153). Alguns jovens tratados como párias agiram de modo a confrontar os seus algozes, integrando as gangs juvenis e, embora fossem uma minoria, seu comportamento servia para, num círculo vicioso, reforçar os estigmas de inferiorização sobre a população do loteamento.

O estudo de Norbert Elias e John Scotson é muito proveitoso do ponto de vista sociológico, pois mostra que a depreciação do outro pode ocorrer entre grupos bem 


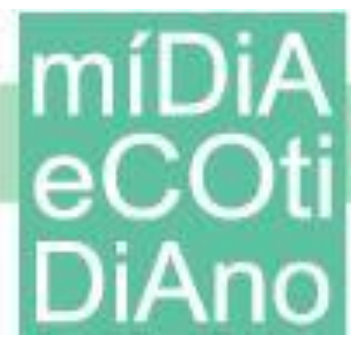

homogêneos do ponto de vista social. Da mesma forma como em Barra do Garças e Aragarças, na cidade inglesa, só o fato de morar em outro local já era motivo suficiente para alguns se considerarem superiores em relação aos outros. Na Inglaterra, a distinção era legitimada por uma maior "tradição" dos moradores antigos, enquanto no vale do Araguaia era simplesmente baseada no local de moradia, ou seja, do outro lado da ponte. Por outro lado, se os insultos dos barragarcenses parecem ter sido bem mais escancarados e jocosos do que os dos "estabelecidos" de Wiston Parva, não houve nenhum tabu que restringisse a sociabilidade entre os moradores das duas cidades. Nesse sentido, parece que a inferiorização do outro foi mais intensa e dramática na Inglaterra do que nas cidades brasileiras, pois lá provocou uma velada exclusão social.

O estudo de Norbert Elias e John Scotson (2000) descreve bem a segmentação entre "estabelecidos" e "outsiders", mas não postula nenhuma hipótese explicativa porque isso acontece. Uma resposta sobre os motivos desta segmentação pode ser encontrada em Sigmund Freud (2010) na sua análise do "narcisismo das pequenas diferenças" na obra Mal-Estar da Civilização, na qual o autor afirma:

Certa vez discuti o fenômeno de justamente comunidades vizinhas, e também próximas em outros aspectos, andarem às turras e zombarem uma da outra, como os espanhóis e os portugueses, os alemães do norte e do sul, os ingleses e os escoceses etc. Dei a isso o nome de "narcisismo das pequenas diferenças", que não chega a contribuir muito para o seu esclarecimento. Percebe-se nele uma cômoda e relativamente inócua satisfação da agressividade, através da qual é facilitada a coesão entre os membros da comunidade (FREUD, 2010, p. 81).

Percebe-se nesta citação, que Freud destaca a universalidade do fenômeno, atingido diferentes países. Contudo, o mais importante é que ele vincula o "narcisismo das pequenas diferenças" ao impulso de agressividade dos seres humanos, algo que provoca uma coesão social entre os membros de um grupo. Isto é, de acordo com o autor, humilhar o outro por meio de piadas ou deixando explícita a sua inferioridade na sociabilidade cotidiana é prazerosa porque é uma forma de fugir das restrições que a civilização impõe ao comportamento humano, principalmente da obrigação inexequível de amar o próximo como a si mesmo. Além disso, a agressão simbólica do outro que ocorre nessas situações provoca satisfação no indivíduo, pois o seu ato passa a ser 


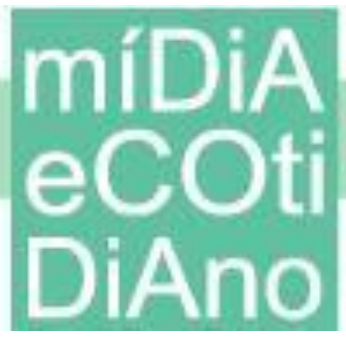

elogiado na comunidade em que ele vive. Tal procedimento corresponde ao mesmo que simular uma situação de guerra, na qual o soldado se torna um herói por praticar atos que em situações normais seriam considerados uma transgressão civilizatória.

Mais importante do que externar os instintos de agressividade que habitam a psique humana é o fato de o "narcisismo das pequenas diferenças" contribuir para a harmonia social. Novamente é lícito comparar com uma situação de uma guerra, em que a animosidade direcionada ao inimigo externo diminui as divisões internas. Nesse sentido, Freud (2010, p. 80-81) afirma ser “possível ligar um grande número de pessoas pelo amor, desde que restem outras para que se exteriorize a agressividade".

Para que essa coesão interna seja estimulada, o outro passa a ser visto de forma estereotipada. É preciso encontrar no outro características que o tornem menos humano. A palavra "narcisismo" justifica-se porque os "estabelecidos" só enxergam a individualidade humana no seu próprio grupo, enquanto os "outros" são reduzidos a um conjunto de estereótipos. Como o "outro" não é igual ao "nós”, justifica-se insultá-lo ou tratá-lo de modo inferiorizado. Desse modo,

[...] ao se elevar alguns traços do outro à categoria de excentricidade, fora esses traços, já não se vê mais nada, sofre-se uma cegueira perceptiva e a sensibilidade torna-se assim estereotipada. Forte recurso psíquico esse que transforma a alteridade em uma caricatura, da qual se pode rir não um riso libertador - mas de escárnio (REINO; ENDO, 2011, p. 25).

O grupo narcisista precisa reduzir o outro a um conjunto vazio de estereótipos para que o mesmo possa ser insultado e humilhado. A cegueira perceptiva transforma o outro num espelho, mas um espelho deturpado, no qual os "estabelecidos" enxergam suas qualidades morais em detrimento dos defeitos dos "outsiders". Isso é bem mais evidente em tempos de internet, quando a antiga fofoca transmitida boca a boca é substituída pelos memes de efeito rápido e devastador.

\section{Os memes como forma de estigmatização dos aragarcenses}

A palavra "meme" foi cunhada pelo biólogo evolucionista Richard Dawkins (2014), divulgada em seu livro “O Gene Egoísta”, significando uma unidade mínima de 
informação que se multiplica de pessoa para a pessoa, propiciando a evolução cultural. De acordo com Dawkins (2014, p. 112), "Mimeme provém de uma raiz grega adequada", mas o biólogo queria "um monossílabo" que se assemelhasse a "gene". Daí sua opção por abreviar mimeme para meme, e segundo ele, "Se servir como consolo, pode-se, alternativamente, pensar que a palavra está relacionada à memória, ou à palavra francesa même". Para justificar a escolha do termo o autor argumenta que:

Da mesma forma como os genes se propagam no "fundo" pulando de corpo para corpo através dos espermatozóides ou dos óvulos, da mesma maneira os memes propagam-se no "fundo" de memes pulando de cérebro para cérebro por meio de um processo que pode ser chamado, no sentido amplo, de imitação. Se um cientista ouve ou lê uma idéia boa ele a transmite a seus colegas e alunos. Ele a menciona em seus artigos e conferências. Se a idéia pegar, pode-se dizer que ela se propaga, si própria, espalhando-se de cérebro a cérebro. É por imitação, em um sentido amplo, que os memes podem replicar-se. Mas, da mesma maneira como nem todos os genes que podem se replicar têm sucesso em fazê-lo, da mesma forma alguns memes são mais bem sucedidos no "fundo" do que outros (DAWKINS, 2014, p. 112-113).

Da biologia, a palavra foi apropriada no contexto da comunicação digital para se referir à propagação repentina e avassaladora de piadas, imagens, vídeos, textos pela rede mundial de computadores (HORTA, 2015, p. 13). As informações em forma de memes remetem, geralmente, a algum acontecimento do cotidiano que tem como finalidade a identificação ou a satirização de um fato. Assim, conforme Cândido e Gomes (2015, p. 1295), “o meme é uma expressão cultural típica da cibercultura. Sua criação se dá de forma colaborativa e seu crescimento é espontâneo. Por isso mesmo, eles costumam surgir em redes sociais".

Os memes facilitam a divulgação de estereótipos propiciando a projeção narcisista dos "estabelecidos" sobre os "outsiders". As piadas e ideias rebaixando a população aragarcense existiam há muito tempo, antes da existência das redes sociais. Elas se difundiam boca a boca por meio da fofoca ou em discursos escritos em livros e jornais. Com as redes sociais premiando os memes com likes, eles se multiplicaram assustadoramente. Alguns indivíduos se tornaram especialistas na produção e divulgação de memes estereotipados como forma de agradar ao seu grupo. 
Para o meme cumprir a sua função, ou seja, espalhar-se nas redes sociais, ele precisa ter uma certa verossimilhança. Um meme que, por exemplo, transmite a ideia de que o Rio de Janeiro é uma cidade feia provavelmente não vai ser bem aceito, mas um que relaciona a cidade com a violência teria grandes chances de se multiplicar. Portanto, os memes que retratam pejorativamente Aragarças são verossímeis para quem os emite e, muitas vezes, até para quem eles insultam. No "narcisismo das pequenas diferenças", há um pacto mútuo entre os "estabelecidos" e os "outsiders" no tocante à aceitação da plausibilidade dos estigmas divulgados.

A circulação viral do meme está diretamente relacionada à capacidade da coletividade de compreender sua linguagem e de a relacionar com o pensamento social e cultural partilhado por aquele grupo, ou seja, o sucesso da "linguagem memética" reflete o conhecimento prévio daquilo que originou o comentário, o escárnio, a crítica e o desabafo. Enfim, a emissão de uma opinião carregada de sentimento (HORTA, 2015, p. 77). Se é por meio da linguagem que se exterioriza as relações culturais e sociais do "mundo" no qual se está inserido demonstrando e expressando pensamentos, pode-se afirmar que os memes produzidos pelos barragarcenses sobre a "cultura e sociedade" aragarcenses buscaram "materializar" a demarcação simbólica do "nós" e o "outro". Desse modo, os memes são uma "ferramenta" discursiva dos barragarcenses que reforça a diferenciação distintiva existente entre as duas municipalidades.

Um exemplo ilustrativo pode ser percebido no seguinte fato: quando um aragarcense responde as postagens ofensivas e/ou depreciativas sua revolta não encontra espaço de resposta e nem poder para expor o que seria a "verdade", pois como salienta Elias e Scotson (2010, p. 131), os falatórios depreciativos atuam em favor do grupo mais forte e coeso, no caso em questão os barragarcenses. Assim, o grupo que busca "defenderse” só confirma sua inferioridade, pois como não são dotados de poder e status comunal suas elucubrações acabam por reforçar aquilo que pretendia ser negado ${ }^{4}$. Os estabelecidos

\footnotetext{
${ }^{4}$ Como exemplo temos uma postagem de ironizava a falta de luz constante na cidade: "Aragarças, cidade que seduz. De dia falta água, de noite falta luz". Em resposta à postagem, a fala de uma moradora de Aragarças: "Essa página deveria ser Aragarcinha mil grau, pq o ibope dela é nossa cidade". Na mesma
} 
- os barragarcenses - dotados de integração grupal usam os memes para defender e enaltecer o grupo ao qual pertencem.

Em outras palavras, as publicações são voltadas para estimular o "orgulho de ser barragarcense" e difamar de modo jocoso os habitantes de Aragarças. Um exemplo disso foi uma publicação em 26 de junho de 2017 do "Poema para Aragarças":

Aragarças terra boa

De riqueza igual não há

Um ladrão rouba a carteira

Outro rouba o celular

Aragarças minha princesa

Terra de encantos mil

O ladrão te assaltou

Lá na Beira Rio

Fonte: Barra do Garças - M11 Gr4u @BG.M11Gr4u5.

A premissa básica dos insultos dos barragarcenses é que Aragarças é um lugar ruim para se morar, bem inferior a cidade de Barra do Garças. No meme a seguir isso fica bem evidente.

postagem, outro retruca: "Barra do Garças: Também não fica para trás, pois, o atual Prefeito é um tremendo porcaria, no ano de 2012, entreguei em suas mãos um Livro chamado a Cabeça do Eleitor, e todo Projeto de como Administrar as necessidades de toda População Barragarcense: Até agora, só maquiou as obras necessárias, para agilizar a vida dos moradores de Barra do Garças. Obs; > APENAS UM EXEMPLO? TRANSPORTE PÚBLICO > DE HORA EM HORA. Só por este detalhe, está mais do que claro, que o Prefeito, é um tremendo de um incompetente...". Disponível em: <https://www.facebook.com/BG.M11Gr4u/photos/a.1743610249201107/2574276139467843/?type=3\&t heater>. Acesso em: 23 jan. 2020.

${ }^{5}$ Disponível em: <https://bit.ly/2PV2YHI>. Acesso em: 06 nov. 2019. 
Figura 1 - Meme sobre morar em Aragarças

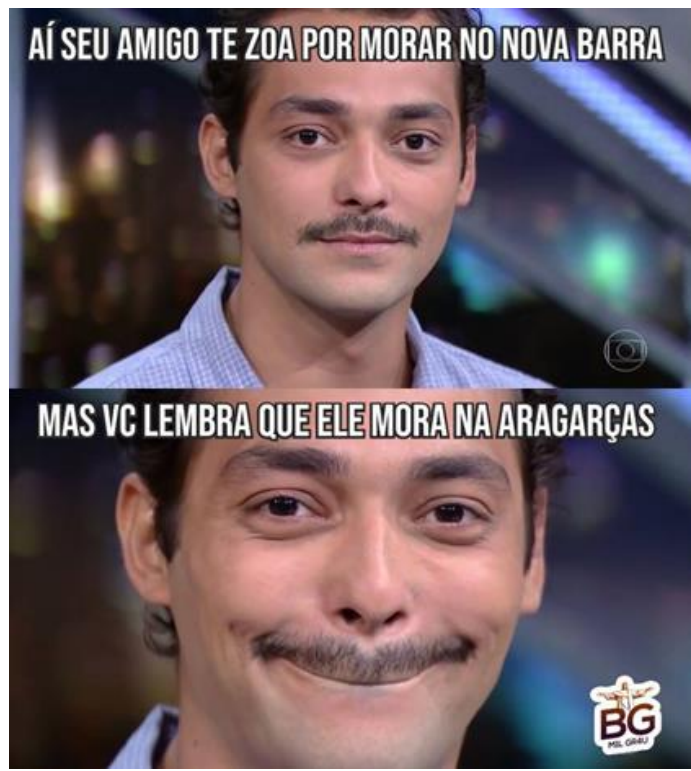

Fonte: Barra do Garças - M11 Gr4u @BG.M11Gr4u6 .

O bairro de Nova Barra está localizado na periferia de Barra do Garças, apresentando problemas de infraestrutura, como asfalto precário, falta de água e alagamento na época das chuvas. Mesmo assim, morar em Aragarças, conforme os memes, seria muito pior, indicando a enorme distância entre as duas cidades. Por isso mesmo, quaisquer tentativas dos aragarcenses de rebater as críticas sobre a sua cidade parece sempre ser antecipada por outro meme, como o exemplo abaixo intitulado "quando alguém fala bem de Aragarças".

Figura 2 - Meme de como é engraçado falar "bem" de Aragarças

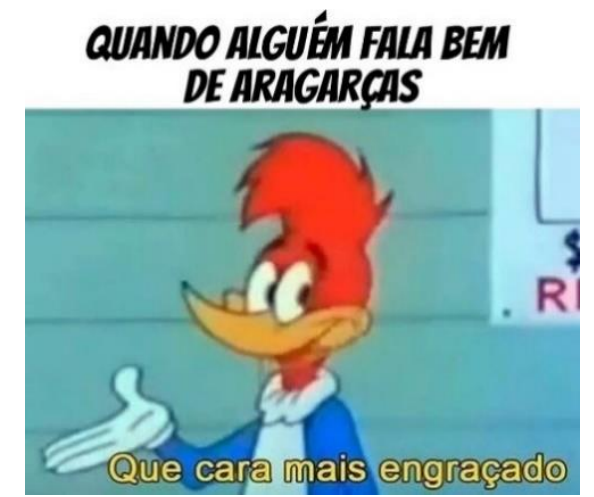

Fonte: Barra do Garças - M11 Gr4u @BG.M11Gr4u

\footnotetext{
${ }^{6}$ Disponível em: <https://bit.ly/2rffabV>. Acesso em: 06 nov. 2019.

${ }^{7}$ Disponível em: <https://bit.ly/2NSNFNf >. Acesso em: 05 nov. 2019.
} 
Mesmo quando há um dissimulado esforço de autocrítica, admitindo-se os problemas de Barra do Garças, a cidade vizinha não é esquecida, como se percebe no meme seguinte:

Figura 3 - Meme advertindo sobre os problemas de Aragarças

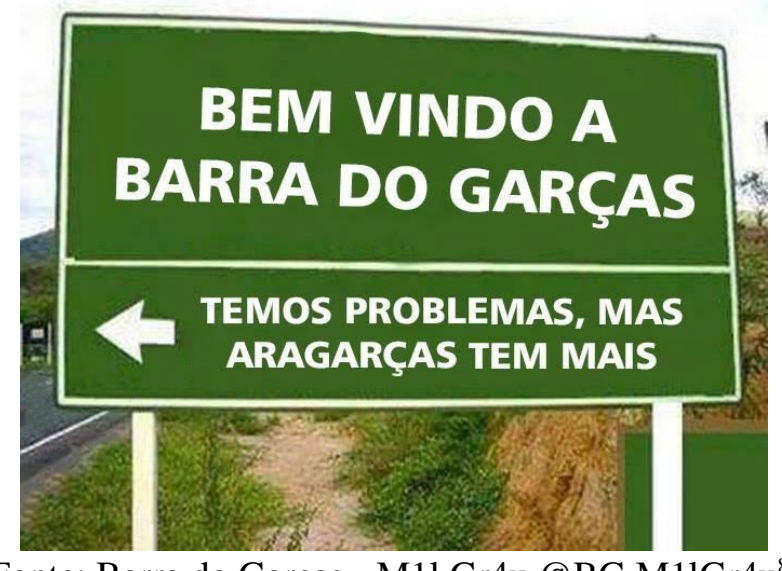

Fonte: Barra do Garças - M11 Gr4u @BG.M11Gr4u

Contudo, pode-se dizer que simplesmente expressar que uma cidade é melhor do que a outra não é suficiente para afirmar que há uma distinção que alimenta "o narcisismo das pequenas diferenças" dos estabelecidos. Afinal, talvez sejam mesmo preciso explicitar de modo detalhado os motivos da suposta superioridade. Nesse sentido, a questão da violência urbana se torna um distintivo importante para a demarcação das diferenças entre a qualidade de vida nas duas cidades. O meme, denominado "ninguém é ateu em Aragarças", aborda essa temática:

\footnotetext{
${ }^{8}$ Disponível em: <https://bit.ly/2Q21BcC〉. Acesso em: 04 nov. 2019.
} 
Figura 4 - Meme "ninguém é ateu em Aragarças"

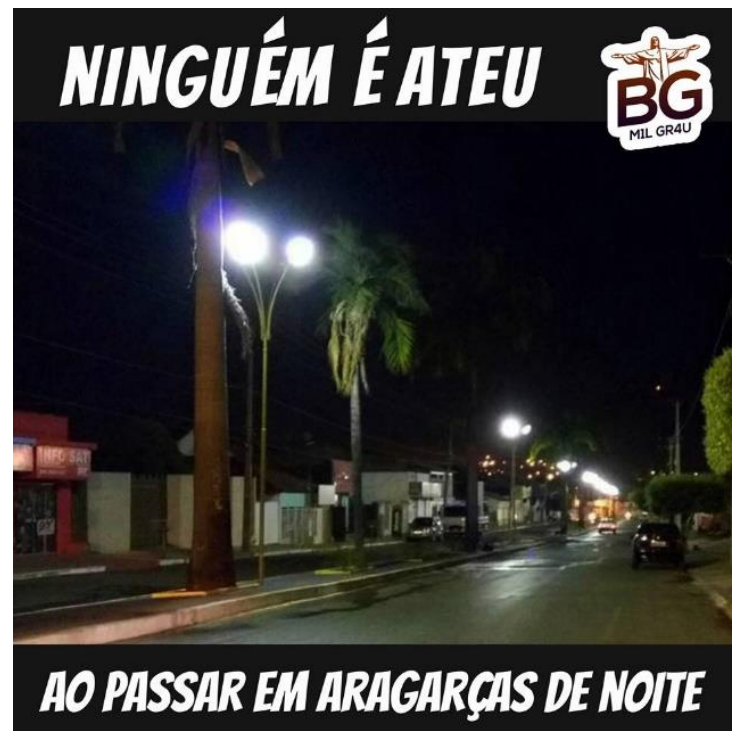

Fonte: Barra do Garças - M11 Gr4u @BG.M11Gr4u .

Deste modo, Aragarças é apresentada como uma cidade perigosa, onde até os ateus reconsideram a sua posição ideológica ante o medo da morte. Aqui, vale conferirmos alguns dados para verificar se $o$ meme faz algum sentido. Começando por uma pesquisa realizada pela Coordenadoria de Estatística e Análise Criminal, da Secretaria de Segurança Pública de Mato Grosso em 2017, confirma-se que a população de Barra do Garças tem um elevado índice de percepção sobre os problemas que envolvem a segurança pública do local. $\mathrm{O}$ estudo apresentado pelo Boletim da Polícia Judiciária de Barra do Garças demonstrou a preocupação da população barragarcense "com o tráfico de drogas, com a entrada de grupos criminosos pela fronteira com Aragarças/GO e o incômodo com a prostituição, possivelmente apoiada pelo turismo incipiente da região" (NOTÍCIAS, 20 jan. 2018). Do ponto de vista mais objetivo, as tabelas a seguir permitem comparar a taxa de homicídios nas duas cidades, entre 2008 e 2013.

\footnotetext{
${ }^{9}$ Disponível em: <https://bit.ly/2NKevXG〉. Acesso em: 05 nov. 2019.
} 
Tabela 1 - Número de Homicídios e homicídios por cem mil habitantes em Aragarças

GO) $2008-2013$

\begin{tabular}{ccccccc}
\hline & $\mathbf{2 0 0 8}$ & $\mathbf{2 0 0 9}$ & $\mathbf{2 0 1 0}$ & $\mathbf{2 0 1 1}$ & $\mathbf{2 0 1 2}$ & $\mathbf{2 0 1 3}$ \\
\hline $\begin{array}{c}\text { Homicídios } \\
\text { 100/mil }\end{array}$ & 33,75 & 39,14 & 16,39 & 32,54 & 21,55 & 31,40 \\
$\begin{array}{c}\text { Número de } \\
\text { homicídios }\end{array}$ & 6 & 7 & 3 & 6 & 4 & 6 \\
\hline
\end{tabular}

Fonte: Tabela elaborada com base nos dados do Deepask ${ }^{10}$.

Tabela 2 - Número de Homicídios e homicídios por cem mil habitantes em Barra do Garças (GO). 2008 - 2013

\begin{tabular}{ccccccc}
\hline & $\mathbf{2 0 0 8}$ & $\mathbf{2 0 0 9}$ & $\mathbf{2 0 1 0}$ & $\mathbf{2 0 1 1}$ & $\mathbf{2 0 1 2}$ & $\mathbf{2 0 1 3}$ \\
\hline $\begin{array}{c}\text { Homicídios } \\
\mathbf{1 0 0 / m i l ~}\end{array}$ & 20,04 & 18,14 & 21,22 & 21,09 & 24,46 & 20,76 \\
$\begin{array}{c}\text { Número de } \\
\text { homicídios }\end{array}$ & 11 & 10 & 12 & 12 & 14 & 12 \\
\hline
\end{tabular}

Fonte: Tabela elaborada com base nos dados do Deepask ${ }^{11}$.

As tabelas demonstram que o número absoluto de homicídios ocorridos em Aragarças é menor do que em Barra do Garças, mas na relação do número com a população, a taxa de homicídio é maior em Aragarças. Seja como for, os números e os índices são próximos um dos outros, não justificando considerar Aragarças, que teve uma média de menos de cinco homicídios/ano entre 2008 e 2013, como uma cidade marcada pela violência urbana. Mesmo assim, o meme "quando alguém fala que aragarcense é tudo ladrão" reforça a suposta índole violenta e marginal dos habitantes da cidade.

\footnotetext{
${ }^{10}$ Disponível em: <https://bit.ly/36FMmJW>. Acesso em: 04 nov. 2019.

${ }^{11}$ Disponíveis em: <https://bit.ly/2NSNZLX>. Acesso em: 04 nov. 2019.
} 


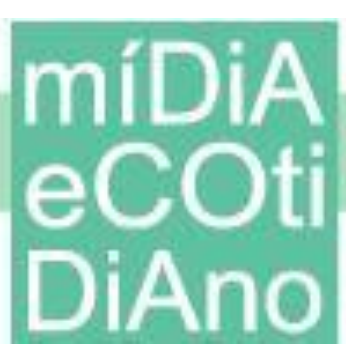

\section{PPGMC}

Figura 5 - Meme "quando alguém fala que aragarcense é tudo ladrão" quando alguem fala que aragarcense é tudo ladrão

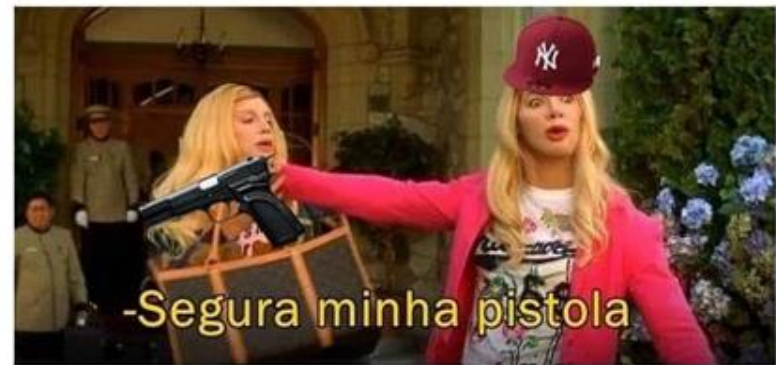

Fonte: Barra do Garças - M11 Gr4u @BG.M11Gr4u ${ }^{12}$.

Também o meme "Cinderela Aragarcense", numa releitura humorística do famoso conto de fadas, explora a suposta elevada criminalidade Aragarcense ao ponto de ser perigoso para uma donzela transitar sozinha à noite. Por isso, a revelação do local de moradia da "Cinderela" é forte o suficiente até para convencer o príncipe apaixonado a abrir mão de sua amada.

\section{Figura 6 - Meme da "Cinderela aragarcense"}

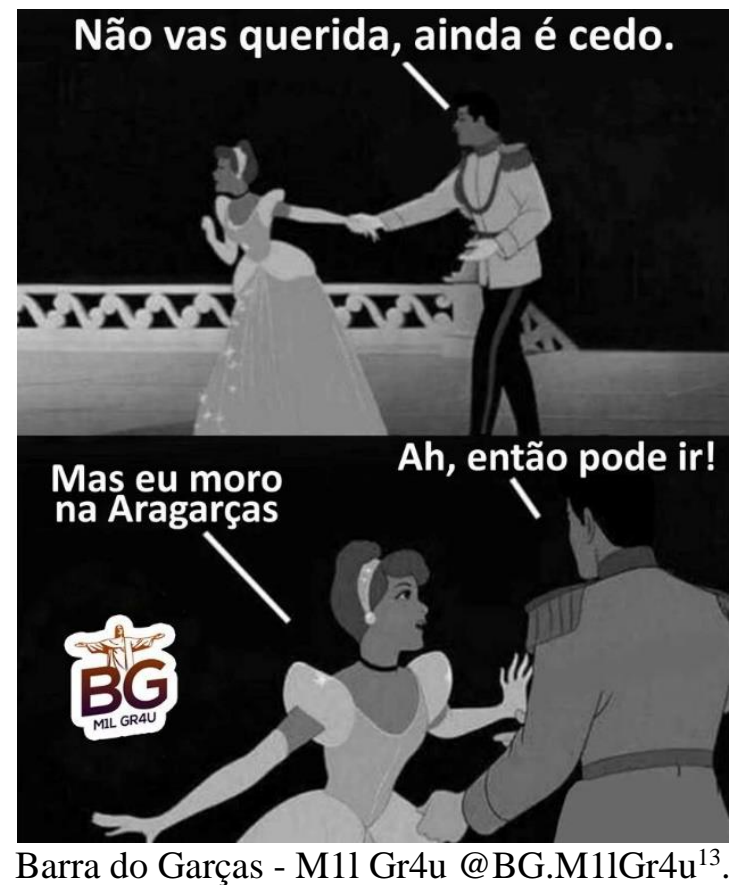

12 Disponível em: <https://bit.ly/33sztRk>. Acesso em: 04 nov. 2019.

${ }^{13}$ Disponível em: <https://bit.ly/2qy231K>. Acesso em: 03 nov. 2019. 
A suposta periculosidade de Aragarças é novamente reforçada com o meme abaixo, que faz uma releitura de uma cena do famoso filme Rei Leão:

\section{Figura 7 - Meme "Rei Leão criticando Aragarças"}

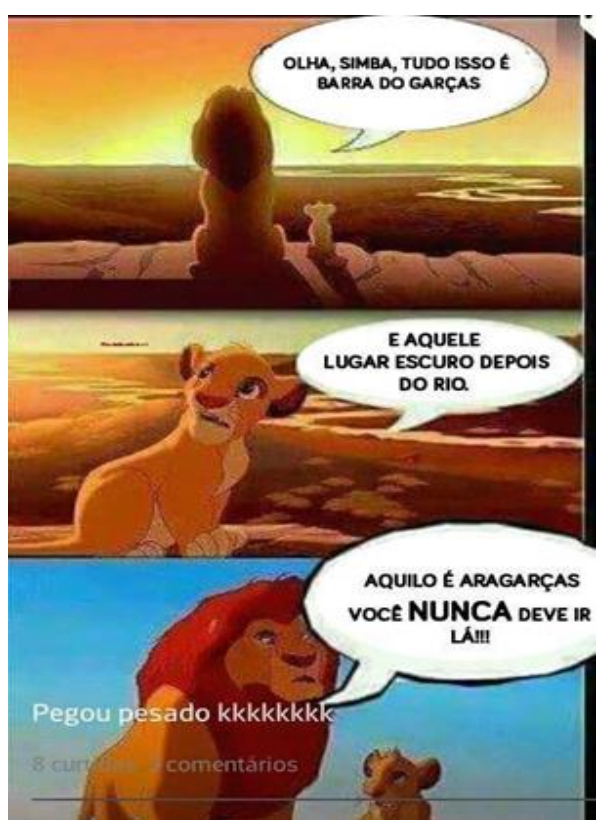

Fonte: Barra do Garças - M11 Gr4u @BG.M11Gr4u ${ }^{14}$.

Uma forma bastante usual de criticar o "outro" é considerá-lo atrasado do ponto de vista cultural. No meme intitulado "Aragarcense ao ver uma rua asfaltada", há uma ridicularização do suposto provincianismo da população rival, ao explorar o embasbacamento diante de um trivial elemento do saneamento urbano, como é o caso do asfalto.

\footnotetext{
${ }^{14}$ Disponível em: <https://bit.ly/2NoG75y>. Acesso em: 03 nov. 2019.
} 
Figura 8 - Meme "aragarcense ao ver rua asfaltada"

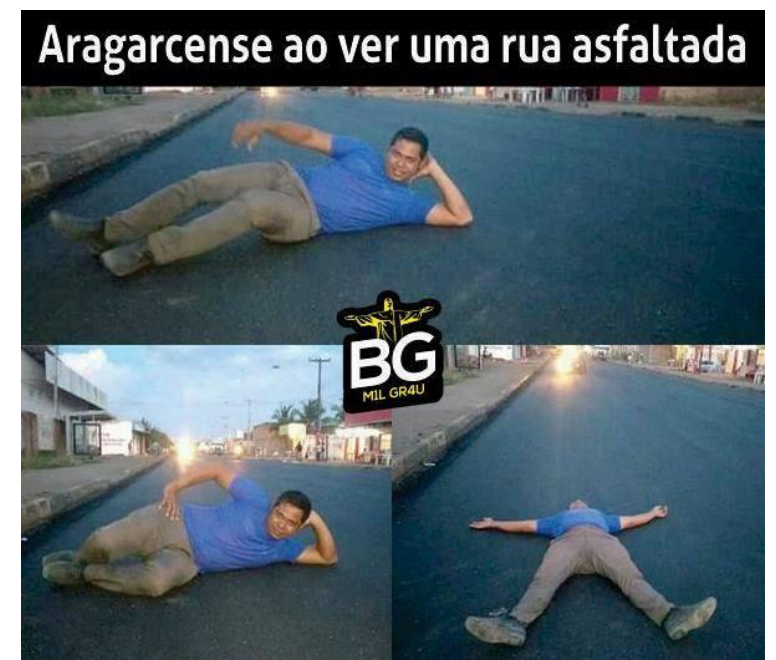

Fonte: Barra do Garças - M11 Gr4u @BG.M11Gr4u15 .

As duas cidades, tão próximas e tão parecidas socioculturalmente, são mostradas nos memes como muito distintas. A ponte sobre o rio Araguaia, principal via para a interação entre os dois lugares, passa a ser interpretada como delimitadora não só da fronteira geográfica, mas também da fronteira cultural.

Figura 9 - Meme "o mundo é diferente da ponte pra cá!"

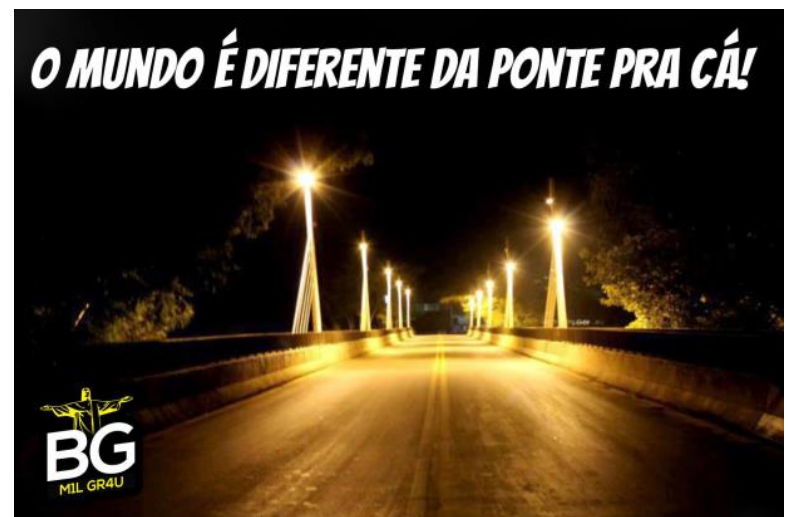

Fonte: Barra do Garças - M11 Gr4u @ BG.M11Gr4u ${ }^{16}$.

Assim, a suposta superioridade de Barra do Garças sobre a cidade rival se assenta a partir da crença de que é uma cidade menos violenta, mais dinâmica e mais moderna.

${ }^{15}$ Disponível em: <https://bit.ly/2NoGlJW>. Acesso em: 04 nov. 2019.

${ }^{16}$ Disponível em: <https://bit.ly/2Nntxn8>. Acesso em: 05 nov. 2019. 


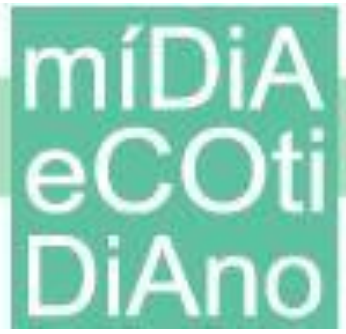

As tabelas a seguir ajudam a comparar os índices demográficos e socioeconômicos entre as duas cidades.

Tabela 3 - Crescimento demográfico dos municípios de Aragarças e Barra do Garças de

1980 a 2010

\begin{tabular}{ccccc}
\hline Municípios & $\mathbf{1 9 8 0}$ & $\mathbf{1 9 9 1}$ & $\mathbf{2 0 0 0}$ & $\mathbf{2 0 1 0}$ \\
\hline Aragarças (GO) & 9.690 & 13.742 & 16.592 & 18.301 \\
Barra do Garças (MT) & 43.601 & 45.712 & 53.092 & 56.560 \\
\hline
\end{tabular}

Fonte: Deepask. Portal da transparência das cidades do Brasil - Aragarças (GO) e Barra do Garças (MT) ${ }^{17}$.

Tabela 4 - PIB (2017) e IDH (2010) de Aragarças (GO) e Barra do Garças (MT)

\begin{tabular}{cccc}
\hline Município & PIB (R\$) & $\begin{array}{c}\text { PIB/PER CAPITA } \\
(\mathbf{R} \$)\end{array}$ & IDH-M \\
\hline Aragarças (GO) & $215.076,23$ & $11.915,62$ & 0,732 \\
Barra do Garças (MT) & $1.747 .384,99$ & $29.744,71$ & 0,748 \\
\hline
\end{tabular}

Fonte: IBGE e Atlas do Desenvolvimento Urbano do Brasil ${ }^{18}$.

A população de Barra do Garças é bem superior, em termos numéricos, à de Aragarças. Contudo, é preciso levar em conta que uma cidade de pouco mais de 50 mil habitantes não possui muitas diferenças culturais em relação a uma de quase 20 mil. Comparada com Cuiabá (MT), que possui mais de 600 mil habitantes, ou com Goiânia (GO), com 1,3 milhões de habitantes, os números demográficos de Barra do Garças são insignificantes. Ela está muito mais próxima a uma cidade pequena do que de uma grande metrópole.

Apesar da evidente superioridade dos índices socioeconômicos de Barra do Garças sobre Aragarças, eles não são suficientes para justificar a retórica da superioridade. O município de Barra do Garças possui uma área territorial de 9.079,291 $\mathrm{km}^{2}$, bem superior à de Aragarças que possui $662,9 \mathrm{~km}^{2}$. A maior área territorial possibilita uma maior exploração do agronegócio, o que aumenta o PIB do município, mas estimula a concentração de renda nos proprietários de terras. As classes médias e

\footnotetext{
${ }^{17}$ Disponível em: <https://bit.ly/2oS9xj4>. Acesso em: 12 ago. 2019.

${ }^{18}$ Disponível em: <https://bit.ly/3bBEmMp> e <http://atlasbrasil.org.br/2013/>. Acessos em: 14 fev. 2020.
} 


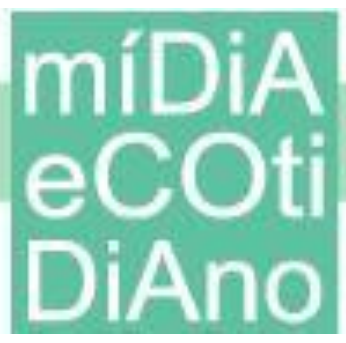

baixas das duas cidades possuem rendas e estilos de vida muito parecidos, como demonstra o IDH bastante similar entre as duas cidades. Fora do contexto local, as proporções distintivas propostas por Barra do Garças parecem descabidas devido a significância da cidade no contexto global.

Portanto, os índices relacionados à violência, à demografia, à atividade econômica e ao desenvolvimento social, por si só, são insuficientes para explicar a retórica da superioridade criada pela população de Barra do Garças sobre Aragarças, como é o caso dos memes apresentados neste artigo. Embora este não tenha sido o foco do artigo, as discussões aqui suscitadas contribuem para pensar sobre a construção do processo distintivo identitário das duas cidades. $\mathrm{O}$ fato de não se ter encontrado nenhum meme que ridicularizasse a cidade de Barra do Garças e a não contestação das chacotas por parte dos aragarcenses também fogem do alcance do estudo e requerem investigação mais aprofundada em uma outra ocasião.

\section{Considerações finais}

A evolução histórica de Aragarças é marcada pela síndrome da decadência, ou seja, pela construção de uma memória identitária que imputa uma superioridade do passado sobre o presente. A cidade teve a sua consolidação urbana a partir da Fundação Brasil Central, quando se tornou referência de desenvolvimento no sertão e recebeu a visita de dois presidentes da República, Getúlio Vargas em 1940 e Juscelino Kubitschek, quando da inauguração da ponte Ministro João Alberto em 1957. Se nesse período a cidade possuía hospitais, aeroporto e fábricas modernas, com a extinção da FBC, Aragarças transforma-se em apenas mais uma das pequenas cidades goianas. Já não bastasse o enfrentamento de sua derrocada, a poucos metros de distância desponta sua vizinha Barra do Garças com rápido crescimento demográfico e econômico, tornando assim ainda mais visível a sua abrupta perda de poder econômico e social.

A psicologia da decadência de Aragarças é similar ao sentimento de quem partilha a ideia de História Monumental, conforme a tipologia desenvolvida por Friedrich Nietzsche (2005). É um tipo de pensamento histórico que acredita que as grandes realizações humanas foram efetuadas no passado e cabe aos homens e mulheres do presente apreciarem esses monumentos de grandeza. Esse tipo de história, para uma 


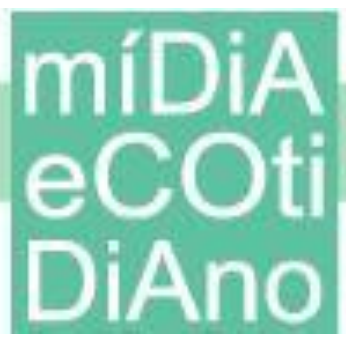

pessoa ativa, pode inspirar a busca de grandeza e a transformação do presente. Mas, para espíritos acomodados ele estimula a apatia, pois faz acreditar que toda a grandeza já foi realizada no passado e o presente será apenas de decadência. "Deixai que os mortos enterrem os vivos" afirmou Nietzsche (2005, p. 90) ironicamente, indicando que a reverência demasiada aos heróis do passado gera acomodação.

Pela análise da produção e repercussão dos memes, fica evidente que em Aragarças predomina essa visão negativa da história monumental. Os tempos heroicos foram os da Expedição Roncador Xingu e os da Fundação Brasil Central quando, por exemplo, um jornal da capital federal produziu uma matéria sobre a região com o título "Em Aragarças começa a civilização do Brasil Central” (A NOITE, 1945). Com o fim dos investimentos federais, a cidade se enquadrou na normalidade do desenvolvimento econômico social típico de uma pequena cidade do interior goiano. Mas para quem viveu tempos áureos e extraordinários, a normalidade foi vista como decadência. As grandezas do passado alimentaram uma visão nostálgica deste, e apática em relação ao futuro, como mostram os conteúdos dos memes analisados.

Historicamente, Barra do Garças, com a sua dinamicidade impulsionada pelo agronegócio dos imigrantes sulistas na década de 1970, passou a espelhar as oportunidades perdidas por Aragarças. Assim, a memória coletiva dos pioneiros aragarcenses reproduziu os discursos da decadência e do atraso e induziu as novas gerações a aceitar a retórica da difamação perpetrada pela cidade vizinha. De acordo com Martins (2015, p. 70), “aquele que mora na cidade de Aragarças, não diz, ou raramente diz que mora, quando perguntado por um indivíduo de outra região, logo a resposta é: moro em Barra do Garças".

Nesse caso, pode-se comparar a situação de Aragarças como sendo similar a dos moradores do loteamento de Wiston Parva, analisada por Elias e Sctotson (2000), que aceitaram os insultos dos habitantes mais tradicionais da cidade. Nos dois lugares é possível perceber indícios de que um círculo perverso pode ter contribuído para que os mais jovens introjetassem e reproduzissem os discursos jocosos passando, então, a ter uma percepção equivocada sobre o lugar em que vivem e sobre si mesmos, considerandose inferiores aos outros. 
Assim, resta esclarecer os motivos da população de Barra do Garças em produzir tais discursos. Nesse caso, a teoria do "narcisismo das pequenas diferenças" de Freud (2010) é bastante útil. Primeiramente, rebaixar o "outro" possibilita elevar o "nós", garantindo maior coesão social ao grupo. Dizer que Aragarças é atrasada e violenta pressupõe que Barra do Garças seja dinâmica, moderna e mais segura. Há, desse modo, uma visão supervalorizada dos aspectos da cidade que produz orgulho e euforia aos seus habitantes, ou seja, uma espécie de cegueira perceptiva em relação à realidade. Se os índices demográficos e sociais de Barra do Garças fossem comparados, por exemplo, com Rondonópolis (MT) ou Rio Verde (GO), cidades bem maiores e mais dinâmicas ${ }^{19}$, poderia haver certa frustração. Mas, ao compará-los com Aragarças, tão próxima ao cotidiano dos moradores, o narcisismo coletivo parece se tornar muito evidenciado.

Outro motivo é que o "narcisismo das pequenas diferenças" é uma estratégia de agressividade simbólica. Agredir o outro é uma prática condenada pela civilização, mas algumas agressões simbólicas são permitidas e provocam euforia coletiva. É o caso dos torcedores de futebol que ficam extasiados ao insultar os torcedores do time rival derrotado. É o caso também de lugares próximos, mas separados o suficiente a ponto de criar uma identidade grupal individualista. Produzir memes sobre Aragarças, desse modo, é uma oportunidade de agredir simbolicamente o outro e ser congratulado pelo grupo como uma espécie de herói de guerra. Isso alimenta a máquina de produção de memes pejorativos sobre a cidade rival.

Enfim, os memes pejorativos produzidos sobre Aragarças podem contribuir para a compreensão das relações de disputas identitárias simbólicas entre dois lugares tão próximos e semelhantes em termos socioeconômicos, mas que aceitaram a retórica da diferença.

\footnotetext{
${ }^{19}$ Enquanto a população de Barra do Garças foi estimada para o ano de 2018 em cerca de 60 mil habitantes, a de Rondonópolis foi estimada em 228 mil e a de Rio Verde em 229 mil. O PIB de Barra do Garças foi mensurado para o ano de 2016 em 1, 7 bilhão de reais, enquanto o de Rondonópolis foi de 7, 6 bilhões e o de Rio Verde foi de 8,3 bilhões no mesmo ano. Os dados foram consultados no site https://pt.wikipedia.org na página respectiva de cada município.
} 


\section{miDiA
DCOA
DiAnd}

\section{Referências}

A NOITE. "Em Aragarças começa a civilização do Brasil Central". A Noite. Rio de Janeiro, de 27 de junho de 1945. Disponível em: 〈http://memoria.bn.br>. Acesso em: 12 ago. 2019.

ARAGARÇAS. Disponível em: <https://pt.wikipedia.org/wiki/Aragar\%C3\%A7as>. Acesso em: 15 jun. 2019.

ARAGUAIA NOTÍCIAS. "Barra do Garças apresenta o melhor índice de segurança de MT". 20 jan. 2018. Disponível em: <https://bit.ly/32tlV6W>. Acesso em: 14 ago. 2019.

BARRA DO GARÇAS - M11 Gr4u. Disponível em:

<https://www.facebook.com/BG.M11Gr4u/>. Acesso em: 12 ago. 2019.

BARRA DO GARÇAS. Disponível em:

<https://pt.wikipedia.org/wiki/Barra_do_Gar\%C3\%A7as>. Acesso em: 12 ago. 2019.

CÂNDIDO, Evelyn Coutinho Rother; GOMES, Nataniel dos Santos. Memes: uma Linguagem Lúdica. Revista Philologus, Ano 21, n. 63. Anais da X CNLF. Rio de Janeiro: CiFEFiL, set./dez. 2015.

CUNHA, Sarah Tavares Corrêa. No vale do Araguaia mato-grossense: uma análise do mercado imobiliário de Barra do Garças no período de 1950-1975. 2006. Dissertação (Mestrado em Economia) - Programa de Pós-Graduação em Economia, Universidade Estadual Paulista, São Paulo.

DAWKINS, Richard. O Gene Egoísta. Tradução Geraldo H. M. Florsheim. São Paulo: Instituto de Biociências da Universidade de São Paulo. 2014. Disponível em: 〈https://bit.ly/36RBCbE〉. Acesso em: 05 nov. 2019.

DEEPASK. Portal da transparência das cidades do Brasil - Aragarças, GO e Barra do Garças, MT. Disponível em: 〈https://bit.ly/36C5w3v〉. Acesso em: 12 ago. 2019.

DINIZ, Zélia dos Santos. Município de Aragarças. 2. ed. Aragarças: ALVCACO, 2016.

ELIAS, Norbert; SCOTSON, John L. Os estabelecidos e os outsiders: sociologia das relações de poder a partir de uma pequena comunidade. Rio de Janeiro: Jorge Zahar, 2000.

FREUD, Sigmund. O mal-estar na civilização. São Paulo: Companhia das Letras, 2010.

HARTOG, François. O espelho de Heródoto: ensaio sobre a representação do outro. Belo Horizonte: Editora da UFMG, 2014.

HORTA, Natália Botelho. O meme como linguagem da internet: uma perspectiva semiótica. 2015. Dissertação (Mestrado em Comunicação) - Programa de Pós-Graduação em Comunicação, Universidade de Brasília, 2015.

IMPRENSA POPULAR. Ed. 02309. Rio de Janeiro, 7 de janeiro de 1957. Disponível em: <https://bit.ly/36KbxLg>. Acesso em: 05 nov. 2019.

LIMA FILHO, Manuel Ferreira. Aragarças: a cidade encantada no sertão de Goiás. Revista Horizontes Antropológicos, Porto Alegre, ano 6, n. 13, p. 65-87, jun. 2000. 
LIMA FILHO, Manuel Ferreira. O desencanto do Oeste. Goiânia: Editora da UCG, 2001.

MACIEL, Dulce Portilho. Aragarças (1943-1968): a moderna urbe na rota para o oeste. Revista Plurais, Anápolis, v. 1, n.4, 2006.

MARTINS, Pollyany Pereira. Dinâmica Socioespacial de Aragarças Goiás: a cotidianidade na construção e estruturação do espaço urbano. 2015. Dissertação (Mestrado em Geografia) Programa de Pós-Graduação em Geografia, Universidade Federal de Goiás, 2015.

NIETZSCHE, Friedrich. "Consideração Intempestiva sobre a utilidade da história e os inconvenientes da história para a vida". In: MELO SOBRINHO, Noéli Correia (sel.). Escritos sobre a história: Friedrich Nietzsche. Rio de Janeiro: PUC; São Paulo: Loyola, 2005. p. 67-98.

REINO, Luiz Moreno Guimarães; ENDO, Paulo Cesar. Três versões do narcisismo das pequenas diferenças em Freud. Trivium, Rio de Janeiro, vol. 3, n. 2, jul./dez. 2011.

RIBEIRO, Hidelberto de Sousa. Políticas territoriais e colonização numa área da Amazônia Oriental. Jundiaí: Paco Editorial, 2016.

RIO VERDE. Disponível em: 〈https://pt.wikipedia.org/wiki/Rio_Verde〉. Acesso em: 17 jun. 2019.

RONDONÓPOLIS. Disponível em: 〈https://pt.wikipedia.org/wiki/Rondon\%C3\%B3polis〉. Acesso em: 14 ago. 2019.

SILVA, Bruna Alves da. "O mundo é diferente da ponte pra cá": a distinção como chave interpretativa da relação entre Aragarças-GO e Barra do Garças-MT (1920-1980). 2019. Dissertação. Mestrado Interdisciplinar em Territórios e Expressão Cultural do Cerrado, Universidade Estadual de Goiás, 2019.

VARJÃO, Valdon. Barra do Garças: migalhas de sua história. Brasília: Senado Federal, 1985. 